\title{
Regulation of Nitrate Reductase Synthesis in the Yeast Candida nitratophila
}

\author{
By A. CANNONS, A. H. ALI AND C. R. HIPKIN* \\ Plant and Microbial Metabolism Research Group, School of Biological Sciences, \\ University College of Swansea, Swansea SA2 8PP, UK
}

(Received 14 August 1985; revised 22 January 1986)

\begin{abstract}
Immunoelectrophoresis, using antibodies raised against homogeneously pure nitrate reductase (NR; EC 1.6.6.2), was used to study the regulation of NR synthesis in Candida nitratophila. Extracts from ammonium-grown cultures did not contain cross-reacting material, but crossreacting material was detected in cultures transferred to nitrogen-free and nitrate medium. The appearance of NR activity in these extracts appeared to be the result of de novo protein synthesis. The possible role of nitrate in the stimulation of active NR synthesis is discussed. Losses of NR activity that occurred in nitrate-grown cultures transferred to ammonium medium correlated with decreases in cross-reacting material.
\end{abstract}

\section{INTRODUCTION}

Assimilatory nitrate reductase (NR) is a highly regulated enzyme in eukaryotic microorganisms. In fungi such as Aspergillus and Neurospora, high NR activity is found in cultures only when they are grown with nitrate or nitrite, in the absence of ammonium (Kinsky, 1961; Sorger, 1965; Garrett, 1972). This has led to a general consensus that NR is 'induced' by nitrate or nitrite and 'repressed' by ammonium or a product of ammonium assimilation. Moreover, increases in NR activity that occur in nitrate-adapting cultures of Neurospora crassa appear to result from de novo synthesis of NR (Bahns \& Garrett, 1980; Amy \& Garrett, 1979). In contrast, in the green alga Chlorella, NR synthesis appears to be derepressed in nitrogen-starved, ammonium-grown cultures (Hipkin \& Syrett, 1977) and there is evidence that repressed cultures contain NR precursors (Funkhouser et al., 1980). Recent research into the regulation of nitrate assimilation in yeasts in our laboratory has shown that these organisms resemble unicellular algae in some respects. Thus, ammonium-grown cultures of Sporobolomyces roseus (Ali \& Hipkin, 1985) and other yeasts, including Candida spp. (Ali, 1985), acquire the capacity to assimilate nitrate after a short period of nitrogen starvation.

In this paper we present results bearing on the role of nitrate in regulation of the synthesis of NR in ammonium-grown cultures of the yeast Candida nitratophila. The structure and properties of highly purified preparations of this enzyme are described in the preceding paper (Hipkin $e t$ al., 1986).

\section{METHODS}

Organism and culture. Candida nitratophila (NCYC 556) was grown as described by Hipkin et al. (1986). Ammonium medium contained $10 \mathrm{mM}-\mathrm{NH}_{4} \mathrm{Cl}$, nitrate medium contained $10 \mathrm{mM}-\mathrm{NaNO}_{3}$ and ammonium nitrate medium contained $10 \mathrm{~mm}-\mathrm{NH}_{4} \mathrm{NO}_{3}$. Nitrogen-free medium was normal medium minus a nitrogen source. Cultures were washed with nitrogen-free medium between transfers. Zero-time culture densities were set to $10^{8}$ organisms $\mathrm{ml}^{-1}$.

Preparation of cell-free extracts. These were prepared in extraction buffer (50 mu-potassium phosphate, $\mathrm{pH} 7 \cdot 5$, containing $5 \mu \mathrm{M}-\mathrm{FAD}$ ) as described by Hipkin et al. (1986).

Abbreviations: BVH, reduced benzyl viologen; FAD, flavin adenine dinucleotide; NR, nitrate reductase. 
Preparation of frozen/thawed cells. Samples of culture $(0.5 \mathrm{ml})$ were harvested in a bench centrifuge and resuspended in $1 \mathrm{ml}$ extraction buffer and frozen at $-16^{\circ} \mathrm{C}$ for $16-24 \mathrm{~h}$. The frozen suspension was thawed slowly at room temperature.

Nitrate reductase $(N R)(E C$ 1 6.6.2) assays. NADH-NR activity was assayed in cell-free extracts (Hipkin et al., 1986) and by a frozen/thawed, whole cell assay. In the whole cell assay, $1 \mathrm{ml}$ suspensions of frozen/thawed cells were incubated with $50 \mu \mathrm{mol} \mathrm{KNO}_{3}$ for $5 \mathrm{~min}$ at $30^{\circ} \mathrm{C}$ before the reaction was started with the addition of $0.5 \mu \mathrm{mol}$ NADH. Reactions were allowed to proceed for $10 \mathrm{~min}$ and then terminated by boiling. Residual NADH was oxidized by the addition of phenazine methosulphate (Scholl $e t$ al., 1974) and nitrite was estimated as described by Hipkin et al. (1986). In this assay a single freeze/thaw cycle renders the yeast cells permeable to $\mathrm{NADH}$, nitrate and nitrite. NADH-NR activity by this assay was expressed as nmol $\mathrm{min}^{-1}\left(\mathrm{ml}\right.$ culture) ${ }^{-1}$. For the in vitro assay, $\mathrm{NR}$ activity was expressed as $\mathrm{nmol} \mathrm{min}^{-1}$ (mg protein) ${ }^{-1}$.

Protein determination. Protein was measured by the method of Bradford (1976), using Bio-Rad protein reagent.

Preparation of antiserum. A 2000-fold purified NR preparation (homogeneous by SDS gel electrophoresis) was used to immunize a male New Zealand White rabbit. Approximately $150 \mu \mathrm{g}$ NR protein in $50 \%$ (v/v) Freund's complete adjuvant was injected subcutaneously into the shaved hindquarters of the rabbit at multiple sites. This procedure was repeated at 2 week intervals on alternate sides of the rabbit until a total of four injections had been given. Then, $10 \mathrm{~d}$ after the final injection, approximately $8 \mathrm{ml}$ blood was collected from the lateral vein of the ear. The blood was allowed to clot and then centrifuged at $40000 \mathrm{~g}$. The supernatant, stored at $-20^{\circ} \mathrm{C}$, served as the antibody preparation.

Immunological techniques. Antibody reaction was tested by Ouchterlony double diffusion (Ouchterlony, 1953) and titration against NR activity.

Crossed immunoelectrophoresis was done in $0.8 \%(\mathrm{w} / \mathrm{v})$ agarose gels $(25 \mathrm{ml})$ on horizontal plates $(10 \times 10 \mathrm{~cm})$ with barbitone buffer ( $30 \mathrm{mM}, \mathrm{pH} 8.4$ ) as the electrolyte. In the first dimension, $20 \mu \mathrm{l}$ crude extract (about $200 \mu \mathrm{g}$ protein) and/or purified NR (about $0.8 \mu \mathrm{g}$ protein) were electrophoresed for $40 \mathrm{~min}$ at $25 \mathrm{~mA}\left(250 \mathrm{~V}\right.$ ) at $4{ }^{\circ} \mathrm{C}$ in gel lacking antibodies. For tandem crosses, two wells were cut in the gel at the cathode end, $5 \mathrm{~mm}$ apart. In the second dimension proteins separated in the first dimension were electrophoresed into agarose gel containing $0.35 \% \mathrm{NR}$ antiserum for a further $2-3 \mathrm{~h}$ under the above conditions. Gels were washed with $0.15 \mathrm{M}-\mathrm{NaCl}$ for $24 \mathrm{~h}$, washed four times with distilled water over a similar period, dried and stained with Coomassie brilliant blue.

Rocket immunoelectrophoresis was done using the horizontal electrophoresis system described above in $0.8 \%$ $(\mathrm{w} / \mathrm{v})$ agarose gels $(25 \mathrm{ml}$ ) containing $0.35 \% \mathrm{NR}$ antiserum. The gel was electrophoresed at $30 \mathrm{~mA}$ for $2 \mathrm{~h}$ followed by $20 \mathrm{~mA}$ for $4 \mathrm{~h}$ at $4{ }^{\circ} \mathrm{C}$. Gels were washed and stained as described above.

\section{RESULTS}

\section{Appearance and disappearance of NR in C. nitratophila}

Preliminary experiments showed that NADH-NR activities measured in frozen/thawed cells of $C$. nitratophila were highest in cultures grown with nitrate as the sole source of nitrogen. In cultures grown on reduced nitrogen sources such as urea, hypoxanthine or L-amino acids (e.g. glutamine, glutamic acid, asparagine, aspartic acid) NR activity was never more than $10 \%$ of the activity measured in nitrate-grown cultures, and was usually less than $4 \%$. Cultures grown with ammonium as sole nitrogen source did not contain measurable NR activity. In contrast, cultures grown with ammonium plus nitrate or ammonium-grown cultures that had been nitrogen-starved for $3 \mathrm{~h}$ contained $25 \%$ and $20 \%$, respectively, of the NR activity of nitrategrown cultures (results not shown). Fig. 1 shows the appearance of NR activity in ammoniumgrown cultures of $C$. nitratophila; it increased slowly during an initial $2 \mathrm{~h}$ period of nitrogen starvation and then increased rapidly after the addition of $10 \mathrm{~mm}$-nitrate. Addition of cycloheximide with the nitrate, or 30 or $60 \mathrm{~min}$ later, resulted in a rapid inhibition of the increase in NR activity.

NR activity was lost from nitrate-grown cultures under various conditions, e.g. transfer of organisms to nitrate medium lacking a carbon source, transfer to nitrogen-free medium or transfer to ammonium medium (results not shown). Losses of NR activity under these conditions were similar, approximately $50 \%$ of the original NR activity being lost after $5 \mathrm{~h}$. When nitrate-grown cultures were transferred to ammonium nitrate medium there was little change in NR activity for the initial $4 \mathrm{~h}$, after which it decreased at a rate similar to that observed with the ammonium-grown culture. NR activity increased in cultures resuspended in fresh nitrate medium; after $4 \mathrm{~h}$ activity had approximately doubled. Thereafter, NR activity decreased. 


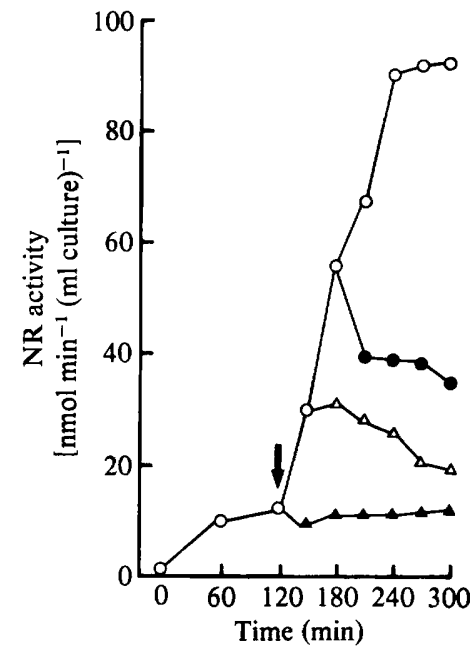

Fig. 1. Effect of cycloheximide on the appearance of NADH-NR activity in $C$. nitratophila. An ammonium-grown culture was washed, transferred to nitrogen-free medium for $120 \mathrm{~min}$, and then supplied with $10 \mathrm{mM}-\mathrm{KNO}_{3}$ (arrowed). Cycloheximide $\left(20 \mu \mathrm{g} \mathrm{m}^{-1}\right)$ was added after $120 \mathrm{~min}(\boldsymbol{\Lambda})$, $150 \mathrm{~min}(\triangle)$ or $180 \mathrm{~min}(\bigcirc) ; O$, no cycloheximide added. NADH-NR activity was measured by the

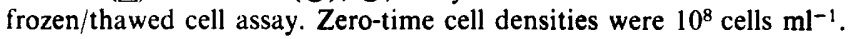

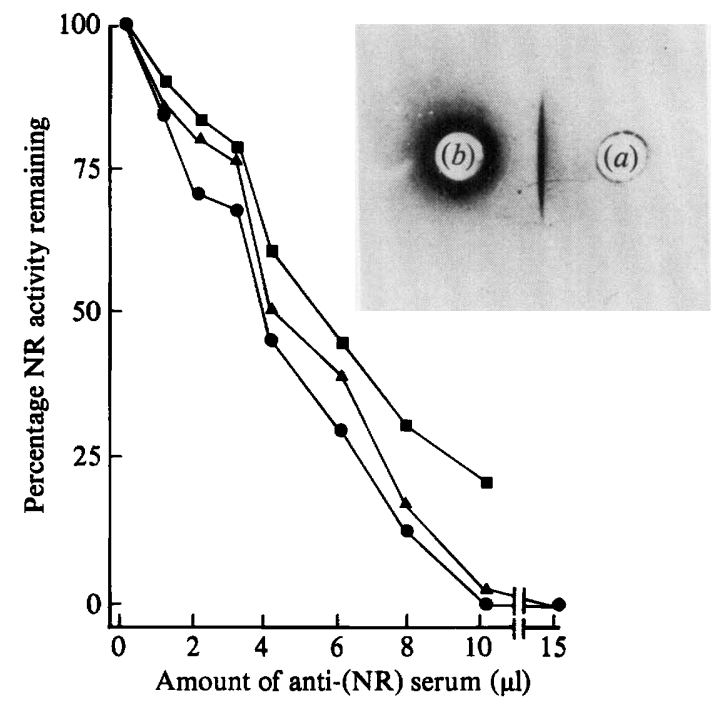

Fig. 2. Effect of anti-(NR) serum on NR activity. Immunological titration of NR. Samples of pure NR were incubated with increasing amounts of anti-(NR) serum at $30^{\circ} \mathrm{C}$ for 30 min and then at $4{ }^{\circ} \mathrm{C}$ for $2 \mathrm{~h}$. Residual NADH-NR activity $(\boldsymbol{O}), \mathrm{BVH}-\mathrm{NR}$ activity $(\boldsymbol{\Lambda})$ and cytochrome $c$ reductase activity $(\boldsymbol{D})$ were then assayed. The $100 \%$ activities were as follows [nmol $\mathrm{min}^{-1}$ (mg protein) ${ }^{-1}$ ]: NADH-NR, 373; BVH-NR, 350; cytochrome $c$ reductase, 383. Null serum had no effect on NR activity. Inset: Ouchterlony double immunodiffusion gel containing $20 \mu \mathrm{l}$ of $(a)$ pure NR and (b) anti-(NR) serum.

\section{Regulation of NR activity in C. nitratophila}

Immunological techniques were used to investigate whether changes in NR activity that occurred under various conditions in C. nitratophila cultures correlated with changes in levels of NR protein. Double diffusion of rabbit NR-antibodies against pure NR in Ouchterlony gels gave a strong precipitin band (Fig. 2, inset). Further, titration experiments showed that the antiserum strongly inhibited the NADH-NR, BVH-NR and cytochrome $c$ reductase activities 

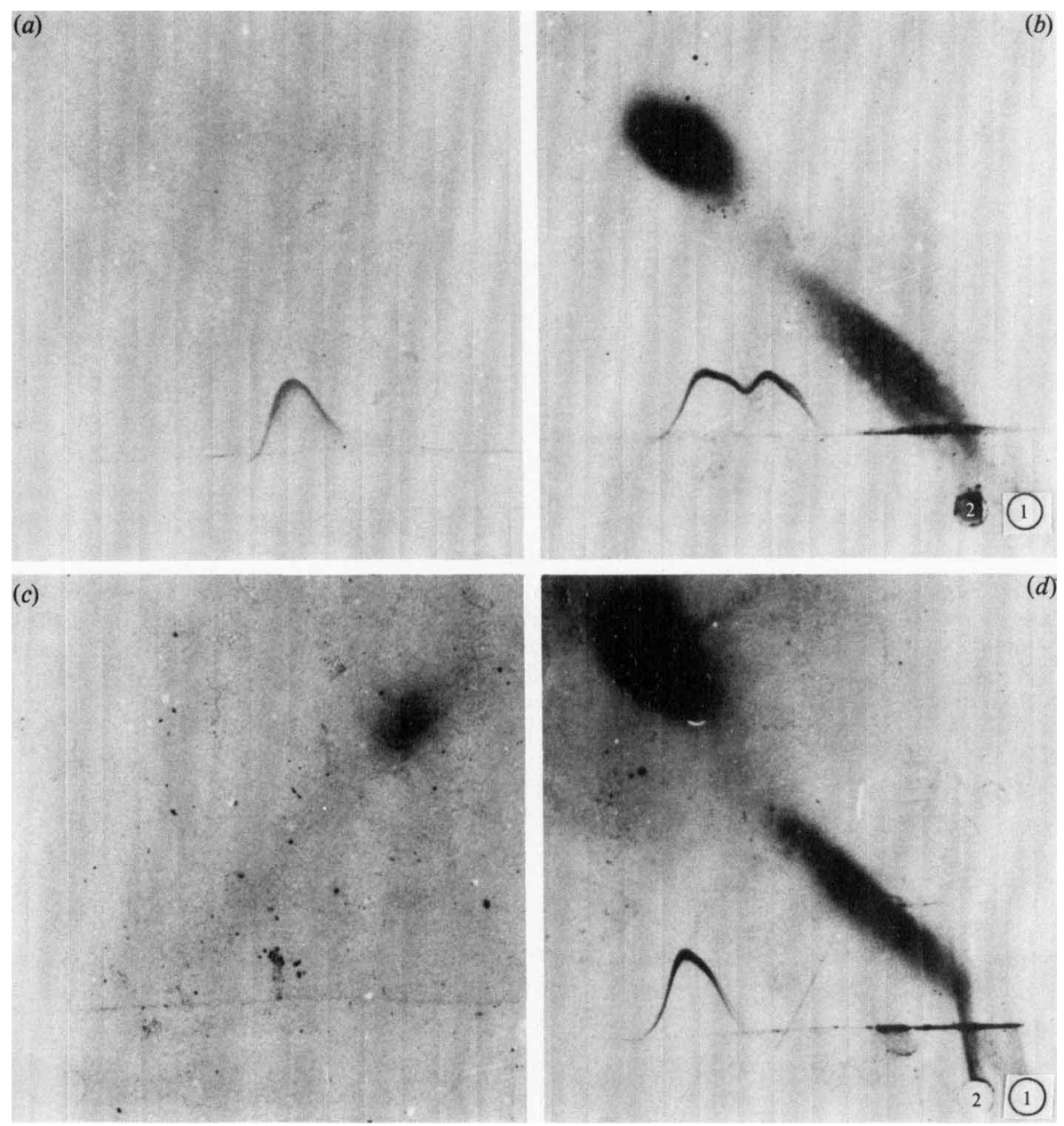

Fig. 3. Crossed immunoelectrophoretic analysis of NR in C. nitratophila. (a) Crossed immunoelectrophoresis of pure NR $(800 \mathrm{ng})$; $(b)$ tandem crossed immunoelectrophoresis of pure NR $(800 \mathrm{ng}) \mathrm{vs}$ cellfree extract $(200 \mu \mathrm{g}$ protein) from a nitrate-grown culture; $(c)$ crossed immunoelectrophoresis of cell-free extract $(200 \mu \mathrm{g}$ protein) from an ammonium-grown culture; $(d)$ tandem crossed immunoelectrophoresis of pure NR ( $800 \mathrm{ng})$ vs cell-free extract $(200 \mu \mathrm{g}$ protein) from an ammonium-grown culture. Precipitation bands were detected after washing in saline and then staining with Coomassie blue and subsequent destaining.

of the enzyme (Fig. 2). Presumably the antibodies recognized and reacted at multiple sites on the enzyme molecule. Preimmune serum had no effect on NR activity.

The appearance of NR activity in ammonium-grown cultures after transfer to nitrogen-free or nitrate medium could result from activation of inactive protein, assembly of precursor protein or a net synthesis of active protein. If activation or assembly were involved then it should be possible to detect cross-reacting material in ammonium-grown cultures by using NR antibodies. To test this, cell-free extracts from ammonium-grown cultures were subjected to crossed immunoelectrophoresis. A single hump-shaped precipitin band was obtained when pure NR was electrophoresed into the antibody-containing gel (Fig. $3 a$ ). A tandem cross of pure NR and crude extract from a nitrate-grown culture produced a contiguous, double-humped precipitin band, without spurs (Fig. $3 b$ ). This indicated identity between pure NR and NR protein in crude extract, as expected. However, extract from an ammonium-grown culture did not produce 


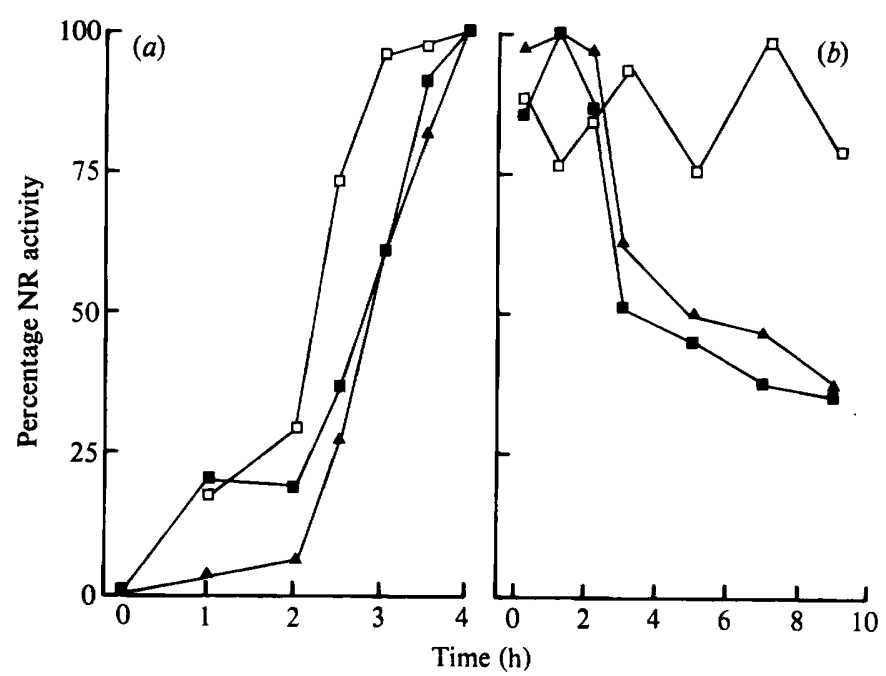

Fig. 4. Appearance and disappearance of NR protein in C. nitratophila. (a) An ammonium-grown culture was washed, nitrogen-starved for $2 \mathrm{~h}$ and then supplied with $10 \mathrm{mM}-\mathrm{KNO}_{3}$. (b) A nitrate-grown culture was washed and transferred to ammonium medium. At each time point indicated samples of cell-free extract were assayed for NADH-NR activity and also subjected to rocket immunoelectrophoresis. $\square$, NR catalytic activity $\left[\mathrm{nmol} \mathrm{min}^{-1}(\mathrm{mg} \mathrm{NR} \text { protein })^{-1}\right] ; \Delta, \mathrm{NR}$ specific activity [nmol $\mathrm{min}^{-1}$ (mg total protein) ${ }^{-1}$ ]; $\square$, NR protein [ $\mu \mathrm{g}$ NR protein (mg total protein) $)^{-1}$. The $100 \%$ values were as follows for $(a)$ and $(b)$ respectively: NADH-NR catalytic activity, 48.3 and $59.2 \mu \mathrm{mol} \mathrm{min}^{-1}$ (mg NR

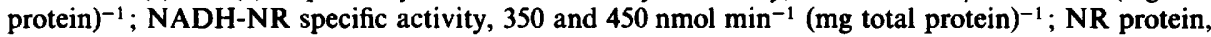
7.38 and $7.6 \mu \mathrm{g} \mathrm{NR}$ protein (mg total protein) ${ }^{-1}$.

a precipitin reaction (Fig. $3 c$ ) and a tandem cross of pure NR and extract from an ammoniumgrown culture only produced one precipitin hump (Fig. $3 d$ ).

Quantitative analysis of the increase in NR protein in nitrogen-free and nitrate-grown cultures was obtained by rocket immunoelectrophoresis. Preliminary experiments using pure NR protein indicated that there was an acceptable, linear relationship between rocket height and amount of NR protein (not shown). Using this sensitive technique it was possible to investigate whether increases in NR activity were correlated with increases in NR protein. Ammonium-grown organisms were nitrogen-starved for $2 \mathrm{~h}$ before addition of nitrate. Cell-free extracts were prepared from these cultures and samples were assayed for NADH-NR activity and subjected to rocket immunoelectrophoresis. Several experiments were done and each gave similar results; Fig. 4(a) shows the results of a typical experiment. No cross-reacting material was detected in zero-time samples. Subsequently during nitrogen starvation, NR protein was detectable after the first hour but did not increase thereafter until nitrate was added. However, the specific activity of NADH-NR activity increased over the whole $2 \mathrm{~h}$ period of nitrogen starvation. After nitrate addition, NR protein and NADH-NR activity increased rapidly. Thus, before nitrate addition, the catalytic activity of NR cross-reacting material increased slowly, whereas after nitrate addition it attained a higher and constant value rapidly.

When a nitrate-grown culture was resuspended in ammonium medium there was a gradual loss of NADH-NR activity, which correlated with decreases in cross-reacting material measured by rocket immunoelectrophoresis (Fig. $4 b$ ). The catalytic activity of NR crossreacting material under these conditions showed fluctuation but little overall change.

\section{DISCUSSION}

The results presented here indicate that NR activity is repressed in $C$. nitratophila cultures grown with ammonium, or other reduced nitrogen sources, as long as nitrate is absent. Moreover, since significant amounts of NR activity can be measured in nitrogen-starved 
cultures and may be sustained for at least $5 \mathrm{~h}$ in the absence of nitrate (Ali, 1985), this suggests that derepression plays a role in the regulation of NR in C. nitratophila. However, nitrate must also play a prominent role in the regulation of NR in this organism since its addition to nitrogenstarved cultures resulted in a large increase in NR activity and cultures grown with ammonium and nitrate contained about $25 \%$ of the fully induced activity of nitrate-grown cultures. Under these conditions there must be a complex balance between nitrate stimulation of NR activity and nitrogen metabolite repression.

Increases in NR activity that occur when ammonium-grown cultures are nitrogen-starved or transferred to nitrate medium could result from regulatory events at the transcriptional, translational or post-translational level. In algae, such as Chlorella, post-transcriptional control has been postulated (Hipkin \& Syrett, 1977) and there is evidence that ammonium-grown cultures synthesize NR precursor protein, which is assembled when cultures are transferred to nitrate medium (Funkhouser et al., 1980, 1983; Funkhouser \& Ramadoss, 1980). In contrast, results obtained from immunological studies here show that precursor NR protein was absent from ammonium-grown cultures of $C$. nitratophila. Similar conclusions were drawn by Amy \& Garrett (1979) for $N$. crassa NR. In fungi, it appears that translation of mRNA, at least, limits the production of active NR in ammonium-grown cultures. Our results show, however, that $C$. nitratophila differs from $N$. crassa in that removal of ammonium alone results in the synthesis of protein, which cross-reacts with NR antibodies, although addition of nitrate stimulates a larger increase in this protein. However, it is significant that the catalytic activity of NR (i.e. activity based on a unit NR protein basis) was higher and reached a steady state rapidly in cultures that received nitrate. We suggest that during nitrogen starvation NR is derepressed but its activity is limited by the assembly of the active enzyme. We would argue, therefore, that addition of nitrate stimulates both the net synthesis and assembly of active enzyme. In this model, nitrate plays a post-translational role in the assembly and stabilization of NR. Similarly, it has been suggested that nitrate stabilizes the formation of active NR in Chlamydomonas (Hipkin et al., 1980, 1985) and plays a post-transcriptional role in the regulation of active NR in Neurospora (Sorger et al., 1974).

Loss of NR from nitrate-grown cultures of $C$. nitratophila occurs when the organisms are deprived of nitrogen or carbon or when they are resuspended in ammonium medium. Similar results have been obtained with other fungi (Lewis \& Fincham, 1970; Hynes, 1973). Results shown here indicate that losses of NR protein that occur in ammonium cultures are not rapid and do not involve an overall change in catalytic activity. This suggests that enzyme inactivation is not responsible for decreases in activity but results from a cessation of enzyme synthesis, dilution and protein turnover.

The role of transcriptional control in the regulation of NR synthesis remains largely unknown. However, recent experiments by us show that ammonium-grown cultures of $C$. nitratophila do not contain poly $\mathrm{A}^{+}$mRNA that translates in vitro into the $95 \mathrm{kDa}$ subunit of $\mathrm{NR}$, whereas nitrogen-starved and nitrate-adapting cultures do (A. Cannons \& C. R. Hipkin, unpublished).

\section{REFERENCES}

ALI, A. H. (1985). Nitrate assimilation in yeasts. PhD thesis, University of Wales, Swansea.

ALI, A. H. \& HIPKIN, C. R. (1985). Nitrate assimilation in the basidiomycete yeast Sporobolomyces roseus. Journal of General Microbiology 131, 1867-1874.

AMY, N. K. \& GARRETT, R. H. (1979). Immunoelectrophoretic determination of nitrate reductase in Neurospora crassa. Analytical Biochemistry 95, 97107.

BaHNS, M. \& Garrett, R. H. (1980). Demonstration of de novo synthesis of Neurospora crassa nitrate reductase during induction. Journal of Biological Chemistry 255, 690-693.

BRADFORD, M. (1976). A rapid and sensitive method for the quantitation of micrograms of protein utilizing the principle of protein-dye binding. Analytical Biochemistry 72, 248-254.

Funkhouser, E. A. \& RAMAdoss, G. S. (1980). Synthesis of nitrate reductase (EC 1.6.6.1) in Chlorella vulgaris. II. Evidence for synthesis in ammonium grown cells. Plant Physiology 65, 944-948.

Funkhouser, E. A., Shen, T. C. \& ACkerman, A. R. (1980). Synthesis of nitrate reductase in Chlorella. I. Evidence for an inactive protein precursor. Plant Physiology 65, 939-943.

Funkhouser, E. A., Gewitz, H. S. \& Vennesland, B. (1983). Accumulation of demolybdo nitrate reductase during induction and its separation from active nitrate reductase in Chlorella. Plant and Cell Physio$\log y 24,1565-1567$. 
GARRETT, R. H. (1972). Induction of nitrate reductase in Neurospora crassa. Biochimica et biophysica acta 264, 481-489.

Hipkin, C. R. \& SyretT, P. J. (1977). Post-transcriptional control of nitrate reductase formation in green algae. Journal of Experimental Botany 28, 1270-1277.

Hipkin, C. R., Al-Bassam, B. A. \& Syrett, P. J. (1980). The role of nitrate and ammonium in the regulation of the development of nitrate reductase in Chlamydomonas reinhardii (2192). Planta 150, 13-18.

Hipkin, C. R., HermanN-Smith, J. A. \& Syrett, P. J. (1985). The role of nitrate, photosynthesis and protein turnover in the formation of nitrate reductase in the nit $\boldsymbol{A}$ mutant of Chlamydomonas. Biochimica et biophysica acta 838, 191-196.

Hipkin, C. R., Ali, A. H. \& Cannons, A. (1986). Structure and properties of assimilatory nitrate reductase from the yeast Candida nitratophila. Journal of General Microbiology 132, 1997-2003.

HYNES, M. J. (1973). The effect of lack of a carbon source on nitrate reductase activity in Aspergillus nidulans. Journal of General Microbiology 79, 155157.
KINSKY, S. G. (1961). Induction and repression of nitrate reductase in Neurospora crassa. Journal of Bacteriology 82, 898-904.

LEWIS, C. M. \& FINCHAM, J. R. S. (1970). Regulation of nitrate reductase in the basidiomycete, Ustilago maydis. Journal of Bacteriology 103, 55-61.

OUCHTERLONY, O. (1953). Antigen-antibody reactions in gels. IV. Types of reactions in coordinated systems of diffusion. Acta pathologica et microbiologica scandinavica 32, 231-240.

Scholl, R. L., HaRper, J. E. \& Hageman, R. H. (1974). Improvements of the nitrite color development in assays of nitrate reductase by phenazine methosulfate and zinc acetate. Plant Physiology 53, 825-828.

SORGER, G. J. (1965). Simultaneous induction and repression of nitrate reductase and TPN cytochrome c reductase in Neurospora crassa. Biochimica et biophysica acta 99, 234-245.

Sorger, G. J., Debanne, M. T. \& Davies, J. (1974). Effect of nitrate on the synthesis and decay of nitrate reductase of Neurospora. Biochemical Journal 140, 395-403. 